\title{
Potential of increasing yield while mitigating climate change in Australian wheat systems: a simulation study
}

\author{
Z. Luo, E. Wang and C. J. Smith \\ CSIRO Agriculture Flagship, GPO Box 1666, Canberra, ACT 2601, Australia. \\ Email: zhongkui.luo@,csiro.au
}

\begin{abstract}
Sustainable management of agroecosystems is required in order to produce more food to feed the growing global population with less environmental costs. The management strategies have to be developed based on local soil and climatic conditions and for specific stakeholders' interests. In this study, we developed a framework to analyse optimal nitrogen $(\mathrm{N})$ requirement for targeting different levels of crop yield and/or climate change mitigation. The Agricultural Production Systems sIMulator (APSIM) was applied at nearuniformly distributed multiple sites to simulate wheat yield in response to $\mathrm{N}$ applications, with the aggregated results tested against the national-level data in Australia. The calibrated model was applied to identify the optimal $\mathrm{N}$ management for different targets. Thereafter, correlation analysis was performed to quantify the relationships between $\mathrm{N}$ demand, yield and climate change mitigation potential (CCMP) and soil and climate variables. The CCMP was defined as the net soil carbon $(\mathrm{C})$ change minus nitrous oxide $\left(\mathrm{N}_{2} \mathrm{O}\right)$ emissions in $\mathrm{CO}_{2}$ equivalents $\left(\mathrm{Mg} \mathrm{CO}_{2}\right.$-eq ha $\left.{ }^{-1} \mathrm{yr}^{-1}\right)$.

At the national scale, the aggregated modelling results could well predict the average wheat yield and soil $\mathrm{C}$ change under the current $\mathrm{N}$ fertilizer input level. Simulation results with different $\mathrm{N}$ application rates indicated that wheat yield could be considerably increased by up to $70 \%$ (from 1.8 to $3.0 \mathrm{Mg} \mathrm{ha}^{-1}$ ) by increasing $\mathrm{N}$ fertilizer input comparing to the current practice. To achieve $90 \%$ of the maximum yield, an average $\mathrm{N}$ input of $110 \mathrm{~kg} \mathrm{ha}^{-1} \mathrm{yr}^{-1}$ was required across the wheat growing regions, which was $\sim 80 \mathrm{~kg} \mathrm{ha}^{-1} \mathrm{yr}^{-1}$ higher than the current $\mathrm{N}$ fertilizer application rates. If we targeted the maximum CCMP per unit area and per unit yield, the simulation results also showed a requirement of increased $\mathrm{N}$ input compared to the current level, which could result in a wheat yield level similar to or higher than $90 \%$ of the maximum yield. Importantly, such increased $\mathrm{N}$ input also led to a substantial decrease in net GHG emissions as compared to the current $\mathrm{N}$ management.

The crop $\mathrm{N}$ demand, yield increase and climate change mitigation potential correlated strongly with sitespecific precipitation, temperature, soil water holding capacity, and antecedent soil carbon content. Across the study area, the $\mathrm{N}$ demand, yield and CCMP varied widely under all four targets (maintaining current crop production, targeting the $90 \%$ of the maximum crop production, targeting the minimum net emissions, targeting the minimum net emissions per unit production). In general, rainfall had significant positive effect on simulated $\mathrm{N}$ demand and yield, and the degree of the effect varied across targets. The plant available water capacity (PAWC) also had significant positive effect on $\mathrm{N}$ demand and yield. However, rainfall had negative effect on CCMP. Compared with rainfall, the effects of temperature on $\mathrm{N}$ demand and yield were relatively neutral. Soil organic $\mathrm{C}$ content had significant positive effect on yield. For CCMP, soil organic $\mathrm{C}$ content had a negative effect. The effects of time period on $\mathrm{N}$ demand, yield and CCMP were negligible under current $\mathrm{N}$ management

The results highlight the opportunity with well-managed intensification to simultaneously increase crop production and mitigate climate change by reducing net GHG emissions in Australian wheat systems. The same opportunity may be present in other low-input dryland cropping systems. The 'win-win' N management recommendations should and can be specified according to local climate and soil conditions by considering the target crop yield and/or climate change mitigation objectives.
\end{abstract}

Keywords: Agricultural intensification, carbon sequestration, food security, greenhouse gas emissions, nitrogen management 


\section{INTRODUCTION}

To meet the increasing global demand for food, feed, fibre and fuel, a $70 \%$ increase in agricultural production by 2050 is required (Foley et al., 2011; Tilman et al., 2011; Garnett et al., 2013). However, agricultural development has had significant negative effect on environment, including degradation in water quality, greenhouse gas emissions (GHG), soil acidification and soil structural degradation (Robertson et al., 2000; Moss, 2008). Thus sustainable agricultural intensification is required to simultaneously increase crop production and reduce environmental costs. The suitable management strategies for such intensification should be site-specific due to variation in soil and climatic conditions.

Wheat is one of the main food crops in most countries, and wheat planting area is the largest globally, compared to other crops (Portmann et al., 2010; FAO, 2015). In 80 of the 127 countries producing wheat, including Australia, where the input is relatively low, current yields are relatively low and are below the world average of $2.97 \mathrm{Mg} \mathrm{ha}^{-1}$ (FAO, 2015). The corresponding area harvested is $\sim 2.4 \times 10^{8}$ ha and accounts for $69 \%$ of global wheat area. In those regions, nitrogen (N) fertilizer use $\left(39 \mathrm{~kg} \mathrm{~N} \mathrm{~h}^{-1}\right.$ on average) is much lower than in regions (111 $\mathrm{kg} \mathrm{N} \mathrm{ha}^{-1}$ on average) where yield is above the average (FAO, 2015). There is a positive correlation between yield and $\mathrm{N}$ fertilizer use, suggesting that better $\mathrm{N}$ management, and increased $\mathrm{N}$ use efficiency, has the potential to increase the global wheat yield. In addition, high yield means high production of crop residue and if retained, it should enhance soil carbon $(\mathrm{C})$ sequestration. However, increasing $\mathrm{N}$ fertilizer application can result in increased nitrous oxide $\left(\mathrm{N}_{2} \mathrm{O}\right)$ emissions from soil, which may off-set the mitigation benefits that increased yield generates through C sequestration (Liu and Greaver, 2009; Zaehle et al., 2011). The responses of yield, $\mathrm{C}$ sequestration and $\mathrm{N}_{2} \mathrm{O}$ emissions to fertilizer management should be systematically quantified in order to evaluate management options that could advance crop yield while mitigating climate change.

In this study, we identified the $\mathrm{N}$ demand for given specific crop yield and/or climate change mitigation targets in Australian wheat systems using a system modelling approach. Correlation analysis was conducted to link $\mathrm{N}$ demand, wheat yield and climate change mitigation potential (CCMP) with soil and climate conditions. The objectives was to identify the best $\mathrm{N}$ fertilizer input rates for various targets of crop yield and climate change mitigation, and assess the underlying controls over the spatial variability in the indentified $\mathrm{N}$ application rates, crop yield and climate change mitigation potential.

\section{MATERIALS AND METHODS}

\subsection{Data sources}

The main data sets include soil profile data at 613 sites and daily weather data (1913-2012) from sites at or close to the soil profile sites. The data sets have been described in detail in Luo et al. (2013). These sites were near-uniformly spread in Australian cereal-growing regions.

\subsection{The APSIM model and simulations}

We used the APSIM model (Keating et al., 2003; Holzworth et al., 2014) to simulate a continuous wheat system for 100 years (1913-2012) at each site, with a major focus on crop yield, soil $\mathrm{C}$ dynamics and $\mathrm{N}_{2} \mathrm{O}$ emissions. The capability of APSIM to simulate soil $\mathrm{C}$ dynamics, crop yield and $\mathrm{N} 2 \mathrm{O}$ emissions have been verified under different cropping and management systems at many locations and over long time periods. This forms the basis for us to use the model in current study. The wheat crop was sown every year depending on rainfall $(>=20$ $\mathrm{mm}$ in five successive days). If the rainfall condition was not met, the crop was sown on the end date of the sowing window. Wheat cultivar was assigned according to sowing date- the earlier the sowing date, the later the maturity type of the wheat cultivar. For simplification, three cultivars representing early, middle and later maturing varieties were selected for the modelling. Crop residues (stem plus leaf) after harvest were retained in the system, representing a common conservation agriculture residue management practice.

To cover the possible fertilizer application rates and identify the best $\mathrm{N}$ requirement for crop yield and/or climate change mitigation (e.g., sequestering $\mathrm{C}$ into the soil and/or reducing $\mathrm{N}_{2} \mathrm{O}$ emissions), simulations were carried out under an $\mathrm{N}$ fertilizer application scenario of $0-250 \mathrm{~kg} \mathrm{~N} \mathrm{ha}^{-1} \mathrm{yr}^{-1}$ in $25 \mathrm{~kg} \mathrm{~N} \mathrm{ha}^{-1}$ increments. In all except the non-fertilizer application scenario, $25 \mathrm{~kg} \mathrm{~N} \mathrm{ha}^{-1}$ was applied as a base fertilizer incorporated into soil at time of sowing, with any additional $\mathrm{N}$ being applied at the stem elongation stage as top-dressing (broadcast). 


\subsection{Calculation of climate change mitigation potential}

The 100-year simulations was discriminated into 100 time periods (i.e., from one year to 100 years). For each of the 100 time periods, under each of the 11 fertilizer application rates, we calculated the annual climate change mitigation potential (CCMP). It is calculated as soil C change minus $\mathrm{N}_{2} \mathrm{O}$ emissions in $\mathrm{CO}_{2}$ equivalents ( $\mathrm{Mg} \mathrm{CO}_{2}$-eq ha ${ }^{-1} \mathrm{yr}^{-1}$ ) using warming potentials of 298 for $\mathrm{N}_{2} \mathrm{O}$ (IPCC, 2013). Positive and negative CCMP indicate the system is a net sink and source of atmospheric $\mathrm{CO}_{2}$-eq, respectively.

Soil $\mathrm{C}$ change was calculated as the difference between soil $\mathrm{C}$ amount after $t(=1,2,3, \ldots, 100)$ years of simulation and soil $\mathrm{C}$ amount at the start of the simulation. Negative and positive change suggests the soil is a source or sink of atmospheric $\mathrm{CO}_{2}$, respectively. Nitrous oxide emissions include direct emissions from the soil and indirect emissions from atmospheric deposition of $\mathrm{N}$ volatilised from the soil as well as from $\mathrm{N}$ leaching/runoff. Direct $\mathrm{N}_{2} \mathrm{O}$ emission was predicted using the APSIM model. For the indirect emissions resulting from $\mathrm{N}$ volatilization and $\mathrm{N}$ leaching/runoff, we adopted the IPCC approach (De Klein et al., 2006).

\subsection{Identification of the optimal $\mathrm{N}$ management}

The baseline for subsequent comparisons was the current practice. We simulated wheat yield across the sites under current $\mathrm{N}$ input level (which was collected from the Agricultural Commodities database). The simulated average yield was compared the yield records in the Agricultural Commodities database. Based on the simulations with different $\mathrm{N}$ application rates, we then identified the $\mathrm{N}$ application rates corresponding to the targets of $90 \%$ of the simulated maximum yield, the maximum CCMP per area and maximum CCMP per unit yield. For each target, $\mathrm{N}$ demand, crop yield and CCMP for each site were calculated. Then, the averages and the $95 \%$ confidence intervals $(\mathrm{CI})$ of $\mathrm{N}$ demand, crop yield and CCMP were estimated by drawing 5,000 bootstrapping samples from the simulations at the 613 sites. These estimates were compared to the baseline case, and the differences were calculated.

\subsection{Environmental drivers for the variation in $\mathbf{N}$ demand, crop yield and CCMP}

$\mathrm{N}$ demand, crop yield and CCMP varied widely across the 613 sites. We hypothesized that the variation could be explained by climate and soil conditions, and focused on four attributes: annual average rainfall and temperature, plant available water capacity of the soil, and initial soil organic carbon content. These attributes are the primary factors influencing yield, soil $\mathrm{C}$ dynamics and/or $\mathrm{N}_{2} \mathrm{O}$ emissions. Across the 100-year simulation, we hypothesized that $\mathrm{N}$ demand, crop yield and CCMP over which we set the targets change over time. In addition, we assumed that the effects of the four climate and soil attributes are different at different time scales.

To test these hypotheses, a linear mixed effects analysis was performed (Gelman and Hill, 2006; Qian et al., 2010), treating the four climate and soil attributes as fixed effects and the time period as a random effect. Before conducting the analysis, all predictors except the time period were standardized using $z$-scores (i.e., subtracting the mean and dividing by the standard deviation). The coefficients estimated based on $z$-scores have the advantage of indicating the relative importance of the predictors: the greater the absolute value of coefficient of the predictor, the more important is the predictor.

\section{RESULTS}

Simulation results with different $\mathrm{N}$ application rates indicated that wheat yield could be considerably increased by increasing $\mathrm{N}$ input rate (i.e., addition $\mathrm{N}$ demand) from the current level (Fig. 1a, b). At the national level, matching $\mathrm{N}$ input to achieve $90 \%$ of the maximum yield could increase average Australian wheat by $\sim 1.2 \mathrm{Mg}$ $\mathrm{ha}^{-1}$ (from $\sim 1.8$ to $3.0 \mathrm{Mg} \mathrm{ha}^{-1}$ ). This would require an average additional $\mathrm{N}$ input of $80 \mathrm{~kg} \mathrm{ha}^{-1} \mathrm{yr}^{-1}$ compared with current $\mathrm{N}$ input level (Fig. 1a). The impact of such an increase in $\mathrm{N}$ input on CCMP depended on the time period for which the yield target was maintained (Fig. 1c). Maintaining current yield under current $\mathrm{N}$ management, the system was a continual source of atmospheric $\mathrm{CO}_{2}$-eq because of soil $\mathrm{C}$ decline and $\mathrm{N}_{2} \mathrm{O}$ emissions (Data not shown). Compared with the current $\mathrm{N}$ management, higher $\mathrm{N}$ input targeting $90 \%$ of the maximum yield, increased CCMP in medium term (around 20 years), but decreased CCMP over the longer term (> 50 years, Fig. 1c).

If we targeted the maximum CCMP per unit area and per unit yield, the simulation results indicated that more $\mathrm{N}$ was required in medium term of less than 20 years (Fig. 1a). This further increase in $\mathrm{N}$ input resulted in predicted wheat yields comparable to, or even higher than $90 \%$ of the maximum yield (Fig. 1b). Importantly, increased $\mathrm{N}$ input resulted in a substantial decrease in net GHG emissions (i.e. much higher CCMP as showed in Fig. 1c) compared to that under current $\mathrm{N}$ management and the $\mathrm{N}$ management targeting $90 \%$ of the 
maximum yield (Fig. 1c). However, $\mathrm{N}$ input has to be adjusted to suit the chosen time period of the two CCMP targets (Fig. 1a). In general, the $\mathrm{N}$ demand shows an asymptotic decrease with time, with a commensurate small loss of yield (Fig. 1b).
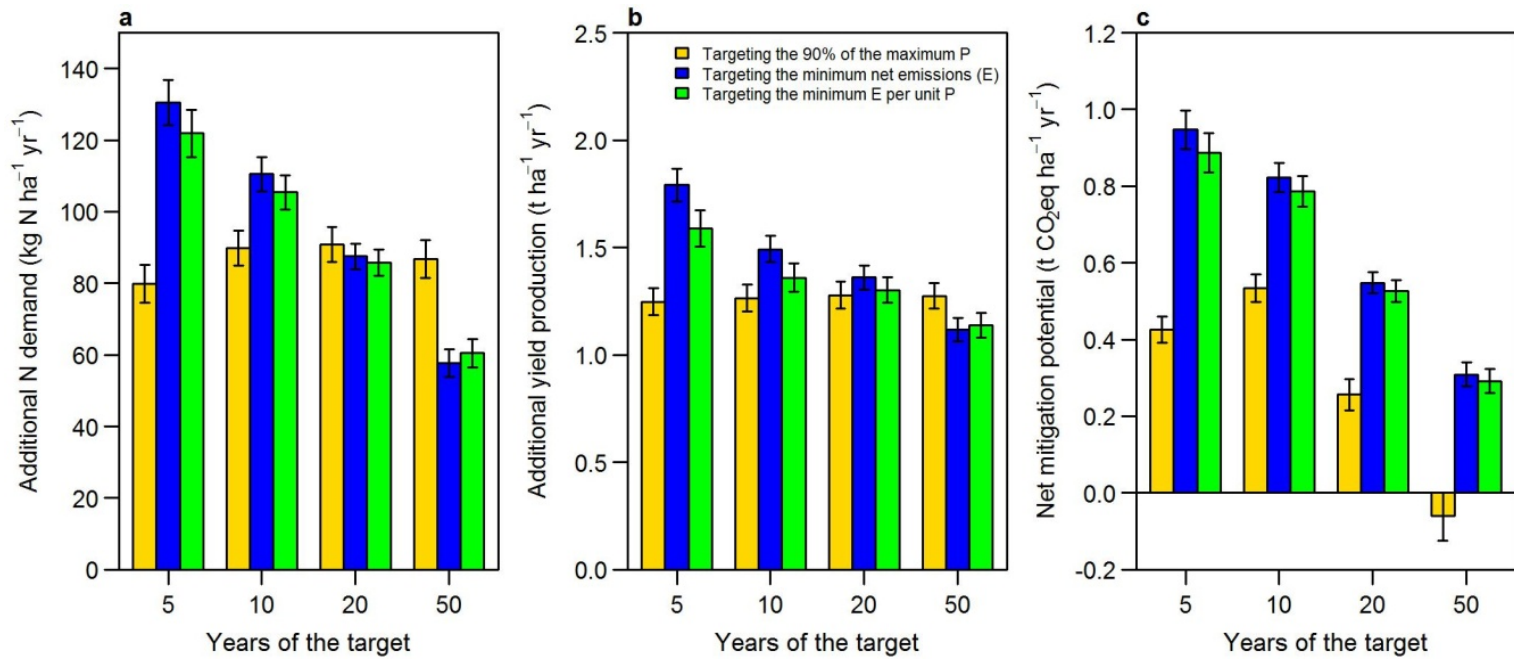

Figure 1. Changes in nitrogen fertilizer demand, wheat yield and net climate change mitigation under three targets relative to that under current $\mathrm{N}$ input level. The maximum production $(\mathrm{P})$ is defined as the $90 \%$ of the maximum yield under no nitrogen limitation. Error bars show the $95 \%$ confidence intervals. Negative values in $\mathrm{c}$ indicate a net source of $\mathrm{CO}_{2}$-eq to the atmosphere.

Across the 613 studied sites, the $\mathrm{N}$ demand, wheat yield and CCMP varied widely under all four targets (data not shown). We assessed the effects of soil and climatic variables and the years of simulation on $\mathrm{N}$ demand, yield and CCMP under the target of minimizing GHG emission. The results indicated that rainfall and PAWC had significant positive effect on simulated $\mathrm{N}$ demand and yield (Table 1). However, rainfall had negative effect on CCMP. Compared with rainfall, the effects of temperature on $\mathrm{N}$ demand and yield were relatively neutral (Table 1).Soil organic $\mathrm{C}$ content had significant positive effect on yield. For CCMP, soil organic C content had a negative effect. $\mathrm{N}$ demand, yield and CCMP were negatively correlated with the length of the simulation (Table 1).

Table 1. Nitrogen requirement, crop yield and climate change mitigation potential (CCMP) as a function of rainfall, temperature, existing soil $\mathrm{C}$ content, plant available water capacity of soil (PAWC), years of the simulation. Coefficient, the coefficient for the predictor of the regression model; SE, the standard error of the coefficient. Bold values indicate that the coefficient is significant at $P<0.05$. ${ }^{\text {a }}$ These variables were converted to $z$-scores.

\begin{tabular}{|c|c|c|c|c|c|c|}
\hline \multirow[b]{2}{*}{ Predictor } & \multicolumn{2}{|c|}{$\begin{array}{l}\text { Nitrogen } \\
\left(\mathrm{kg} \mathrm{ha}^{-1}\right)\end{array}$} & \multicolumn{2}{|c|}{$\begin{array}{c}\text { Yield } \\
\left(\mathrm{Mg} \mathrm{ha}^{-1}\right)\end{array}$} & \multicolumn{2}{|c|}{$\begin{array}{c}\text { CCMP } \\
\left(\mathrm{Mg} \mathrm{CO}_{2} \text {-eq ha }{ }^{-1} \mathrm{yr}^{-1}\right)\end{array}$} \\
\hline & Coefficient & SE & Coefficient & $\mathrm{SE}$ & Coefficient & SE \\
\hline Intercept & 98.73 & 5.26 & 3.4 & 0.049 & 0.03 & 0.046 \\
\hline Rainfall $^{\mathrm{a}}$ & 27.4 & 0.84 & 0.75 & 0.019 & -0.18 & 0.016 \\
\hline Temperature ${ }^{\mathrm{a}}$ & -10.46 & 1.49 & -0.16 & 0.0083 & -0.12 & 0.013 \\
\hline Current soil $\mathrm{C}^{\mathrm{a}}$ & -5.24 & 0.4 & 0.08 & 0.0072 & -0.22 & 0.0061 \\
\hline PAWC $^{a}$ & 1.95 & 0.56 & 0.36 & 0.0086 & 0.023 & 0.0071 \\
\hline Year & -0.09 & 0.044 & -0.1 & 0.00067 & -0.00029 & 0.00023 \\
\hline
\end{tabular}

\section{DISCUSSION AND CONCLUSIONS}

Our results demonstrate that in low input cropping systems, $\mathrm{N}$ management targeting the maximum CCMP (per area or per unit yield) can also increase crop production. Although our study only focused on the wheat systems in Australia, the results should be applicable to other cropping systems and regions as the dominant effect of nutrient availability on crop growth can be generalized, as can the processes controlling soil $\mathrm{C}$ dynamics and $\mathrm{N}_{2} \mathrm{O}$ emissions as simulated in this study. Poor and developing countries, often afflicted by 
hunger and poverty, comprise the majority of the low-input cropping regions. Increasing $\mathrm{N}$ input in those regions could help meet food demand, reduce the pressures for land clearing and poorly planned agricultural expansion, and help mitigate climate change. In contrast, rich, developed and/or fast developing countries have sometimes adopted intensive or even excessive use of fertilizers, inducing serious environmental problems such as acidification and eutrophication (Bouwman et al., 2002; Guo et al., 2010). Exploiting the benefits of fertilizers and transferring the relevant technologies to those poor regions (e.g., achieving high $\mathrm{N}$ use efficiency) has the potential to increase food production as well as help mitigate climate change at the global scale. To design appropriate farm-level $\mathrm{N}$ management strategies it is important to consider the water availability, temperature, soil water holding capacity, and soil organic $\mathrm{C}$ content at the local scale, along with local yield and climate change mitigation targets.

\section{ACKNOWLEDGEMENTS}

This study was funded by the Department of Agriculture (DoA) and the Grain Research and Development Corporation (GRDC) of Australia.

\section{REFERENCES}

Bouwman, A.F., Van Vuuren, D.P., Derwent, R.G., Posch, M., 2002. A Global Analysis of Acidification and Eutrophication of Terrestrial Ecosystems. Water, Air, \& Soil Pollution 141, 349-382.

De Klein, C., Novoa, R.S.A., Ogle, S., Smith, K.A., Rochette, P., Wirth, T.C., 2006. $\mathrm{N}_{2} \mathrm{O}$ emissions from managed soils, and $\mathrm{CO}_{2}$ emissions from lime and urea application. 2006 IPCC Guidelines for National Greenhouse Gas Inventories, p. 53.

FAO, 2015. Statistic Division of the Food and Agriculture Organization of the United Nations. http://faostat3.fao.org/home/E.

Foley, J.A., Ramankutty, N., Brauman, K.A., Cassidy, E.S., Gerber, J.S., Johnston, M., Mueller, N.D., O/'Connell, C., Ray, D.K., West, P.C., Balzer, C., Bennett, E.M., Carpenter, S.R., Hill, J., Monfreda, C., Polasky, S., Rockstrom, J., Sheehan, J., Siebert, S., Tilman, D., Zaks, D.P.M., 2011. Solutions for a cultivated planet. Nature 478, 337-342.

Garnett, T., Appleby, M., Balmford, A., Bateman, I., Benton, T., Bloomer, P., Burlingame, B., Dawkins, M., Dolan, L., Fraser, D., 2013. Sustainable intensification in agriculture: premises and policies. Science 341, 33-34.

Gelman, A., Hill, J., 2006. Data analysis using regression and multilevel/hierarchical models. Cambridge University Press.

Guo, J.H., Liu, X.J., Zhang, Y., Shen, J.L., Han, W.X., Zhang, W.F., Christie, P., Goulding, K.W.T., Vitousek, P.M., Zhang, F.S., 2010. Significant Acidification in Major Chinese Croplands. Science 327, 1008-1010.

Holzworth, D.P., Huth, N.I., Zurcher, E.J., Herrmann, N.I., McLean, G., Chenu, K., van Oosterom, E.J., Snow, V., Murphy, C., Moore, A.D., 2014. APSIM-evolution towards a new generation of agricultural systems simulation. Environ. Modell. Softw. 62, 327-350.

Keating, B.A., Carberry, P.S., Hammer, G.L., Probert, M.E., Robertson, M.J., Holzworth, D., Huth, N.I., Hargreaves, J.N., Meinke, H., Hochman, Z., 2003. An overview of APSIM, a model designed for farming systems simulation. Eur J Agron 18, 267-288.

Liu, L., Greaver, T.L., 2009. A review of nitrogen enrichment effects on three biogenic GHGs: the CO2 sink may be largely offset by stimulated N2O and CH4 emission. Ecology Letters 12, 1103-1117.

Luo, Z., Wang, E., Bryan, B., King, D., Zhao, G., Pan, X., Bende-Michl, U., 2013. Meta-modeling soil organic carbon sequestration potential and its application at regional scale. Ecol Appl 23, 408-420.

Moss, B., 2008. Water pollution by agriculture. Philosophical Transactions of the Royal Society B: Biological Sciences 363, 659-666.

Portmann, F.T., Siebert, S., Döll, P., 2010. MIRCA2000 - Global monthly irrigated and rainfed crop areas around the year 2000: A new high-resolution data set for agricultural and hydrological modeling. Global Biogeochem Cy 24, GB1011.

Qian, S.S., Cuffney, T.F., Alameddine, I., McMahon, G., Reckhow, K.H., 2010. On the application of multilevel modeling in environmental and ecological studies. Ecology 91, 355-361.

Robertson, G.P., Paul, E.A., Harwood, R.R., 2000. Greenhouse gases in intensive agriculture: contributions of individual gases to the radiative forcing of the atmosphere. Science 289, 1922-1925.

Tilman, D., Balzer, C., Hill, J., Befort, B.L., 2011. Global food demand and the sustainable intensification of agriculture. Proceedings of the National Academy of Sciences 108, 20260-20264.

Zaehle, S., Ciais, P., Friend, A.D., Prieur, V., 2011. Carbon benefits of anthropogenic reactive nitrogen offset by nitrous oxide emissions. Nature Geoscience 4, 601-605. 